\title{
Indexical Evaluation of Heavy Metal Concentrations in Soil around Industrial Area of Ajao-Estate Lagos Nigeria
}

\author{
Bernadette U Ukah*(i), Ogbonnaya Igwe, and Oyem E Ubido \\ Department of Geology, University of Nigeria, Nsukka, Nigeria
}

\begin{abstract}
Heavy metals pollution in soils has become a serious threat to many countries especially developing countries like Nigeria due to increase in urbanization and industrialization. In this study several indexical models (contamination factor (CF), contamination degree $(\mathrm{mCd})$, geo-accumulation index $\left(\mathrm{I}-{ }_{\text {geo }}\right)$, pollution load index (PLI), and Nemerow integrated pollution index (NIPI)) were used to assess the pollutions, pollution sources and ecological effect of heavy metals ( $\mathrm{Fe}, \mathrm{Zn}, \mathrm{Pb}, \mathrm{Cd}, \mathrm{Mn}$, $\mathrm{Cu}, \mathrm{Cr}$, and $\mathrm{Ni}$ ) in industrial soils from Ajao area, Lagos. All the metals are within the standard of Department of Petroleum Resources (DPR) except Cd (1.160, 1.020, and 1.080) mostly around the industrial wastewater dislodging Point. Pb has no significant correlation with other heavy metals in the soil samples whereas other heavy metals, strong to medium positive correlation exist between these heavy metals at 2-tailed significant levels of 0.01 and 0.05 suggests that these metals have the same anthropogenic origin. The 1-geo calculated for heavy metals suggest that all the samples are unpolluted. CF of the heavy metals was in the range of low contamination except $\mathrm{Cd}$ that showed moderate contamination. $\sum R I$ of all the heavy metals analysed in this study pose low ecological risks except for $\mathrm{Cd}$ which showed moderate potential to considerable potential ecological risk. NIPI result showed some of the samples were slightly polluted while some were heavily polluted. For $\mathrm{mCd}$, all the samples were within very low degree of contamination. The PLI result shows that samples were within unpolluted range in the PLI classification scheme.
\end{abstract}

\section{Keywords}

Geoaccumulation index, Nemerow integrated pollution index, Pollution load index, Contamination factor (CF), Contamination degree, Ecological risk index

\section{Introduction}

The evaluation of soil degradation particularly the quality of soil has increased as soil is an important component of the earth, functioning both in the production of food, storage of water, fibres and in the maintenance of environmental quality [1]. Reduction in soil quality has posed serious challenge to increasing agricultural productivity, economic growth, and healthy environment owing to inappropriate land use and soil management and natural causes [2,3]. Soil is defined as being polluted when pollutants/metal concentrations in its bulk horizons exceed baseline values (allowable standard limits) $[4,5]$. Polluted soil has negative effects on food safety as well as result in increased health risks [6-8]. Soil polluted with heavy metals is of one the most ecological problems because it is related directly to the human health since these metals accumulate in various ecosystems, reflect in both the plant, animal and microbiological processes and finally enter humans through the food chain [9-14]. Most often, these heavy metals are transferred into human tissues through dermal contact absorption, inhalation of soil particles in the form of dust and consumption of contaminated vegetables and foods [15-18]. Although some heavy metals like $\mathrm{Zn}, \mathrm{Cu}$, and $\mathrm{Cr}$ play essential role in biochemical processes, most organisms required these metals in a small amount for healthy growth but become toxic at higher concentration $[19,20]$. But heavy metals like $\mathrm{Cd}, \mathrm{Pb}, \mathrm{Ni}$ etc are not essential and do not cause deficiency disorders if absent, rather, they are toxic even at low concentration [19].

The presence of some heavy metals in the soil are dangerous unlike other pollutants because they are nondegradable and take time to vanish, they geo-accumulate

*Corresponding author: Bernadette U. Ukah, Department of Geology, University of Nigeria, Nsukka Road, Nsukka, 410001, Nigeria, Tel: +234-7038479934

Accepted: June 11, 2021

Published online: June 14, 2021

Citation: Ukah BU, Igwe O, Ubido OE (2021) Indexical Evaluation of Heavy Metal Concentrations in Soil around Industrial Area of Ajao-Estate Lagos Nigeria. J Soil Water Sci 5(1):184-192 
and thereby exceed their respective allowable standard limits [21,22]. Their concentration in the soil is a major problem to sustainable water quality, because the soil controls the quality of water especially the underwater which in turn poses a major threat to human health if the water finally gets contaminated $[21,23]$. Sources of heavy metals can be classified into two; natural and anthropogenic sources. Through natural processes like weathering, parent rocks usually release heavy metals into the soil. Outside the natural sources, anthropogenic activities, such as industrial wastewater, poor solid waste management, automobile workshop, discharge of sewage, mining activities, irrigation with polluted water, and the application of pesticides and fertilizers in farms is another source of heavy metals in the soil $[9,10,24-26]$. The most important origin of heavy metals is related to industrial activities from industries like chemistry, mining, iron and steel industry, metallurgy, building and electronics industry, automobile workshops etc and industrial emissions such as fuel combustion, and waste management and transport [27].

Irrespective of various origins or sources of heavy metals, their toxic effects, even at low concentrations, have drawn the attention of many researchers [9]. Because people in urbanised and industrialized areas, with high human populations and anthropogenic activities are more exposed and vulnerable to the negative effects of heavy metal contamination, hence soil quality assessment is becoming a research topic of increasing interest worldwide [11,21,2830]. Soil quality changes with time and can indicate whether the soil condition is sustainable or not $[31,32]$. Evaluation of heavy metal concentration in the soil is important so that changes in soil quality can be recognised as they occur with the aid of established baseline. Effective evaluation of soil contamination with heavy metals is the use of suitable indices of pollution/contamination that can be regarded as a tool and guide for a comprehensive geochemical assessment of the soil environmental status. These indices can also indicate whether the accumulation of heavy metals was due to natural processes or as a result of anthropogenic activities, hence, the indices of pollution can also help in monitoring the amount of environmental risk and the changes in soil due to the accumulation of heavy metals [27]. Furthermore, the indices help to protect and improve long-term agricultural productivity, water quality, and habitats of all organisms including human being [32-35].

The study area Ajao-Estate lies latitudes $6^{\circ} 30^{\prime}$ to $6^{\circ} 33^{\prime}$ $\mathrm{N}$ and longitudes $3^{\circ} 18^{\prime}$ to $3^{\circ} 22^{\prime} \mathrm{E}$ (Figure 1 ). It is underlain by two distinct Lithologies; the coastal plain sand and the alluvial river sand. Both sands are part of Dahomey Basin [21]. Coastal plain sand is the aquifer in the study area though very shallow in general $[21,36]$. The dominant activities in Ajao-Estate include commerce, industrial food/ wine production processes, automobile workshops and factories with inadequate industrial wastewater disposal [21]. In order to determine changes in the soil quality and the soil environmental status of this industrial area, AjaoEstate, indexical evaluation of the heavy metals were carried out. To achieve this, various environmental pollution index were modeled in order to ascertain the fragility of the soil and for understanding how improved management might strengthen its resilience [37]. These indices include; geoaccumulation index (Igeo), Nemerow integrated pollution index (NIPI), pollution load index (PLI), enrichment factor (EF), contamination factor (CF), contamination degree $(\mathrm{mCd})$ and ecological risk index (ERI) [11,18,21,23].

\section{Materials and Method}

\section{Data sampling and analysis}

A total of twenty one (21) soil samples including fifteen (15) soil samples from the study site and six (6) from the
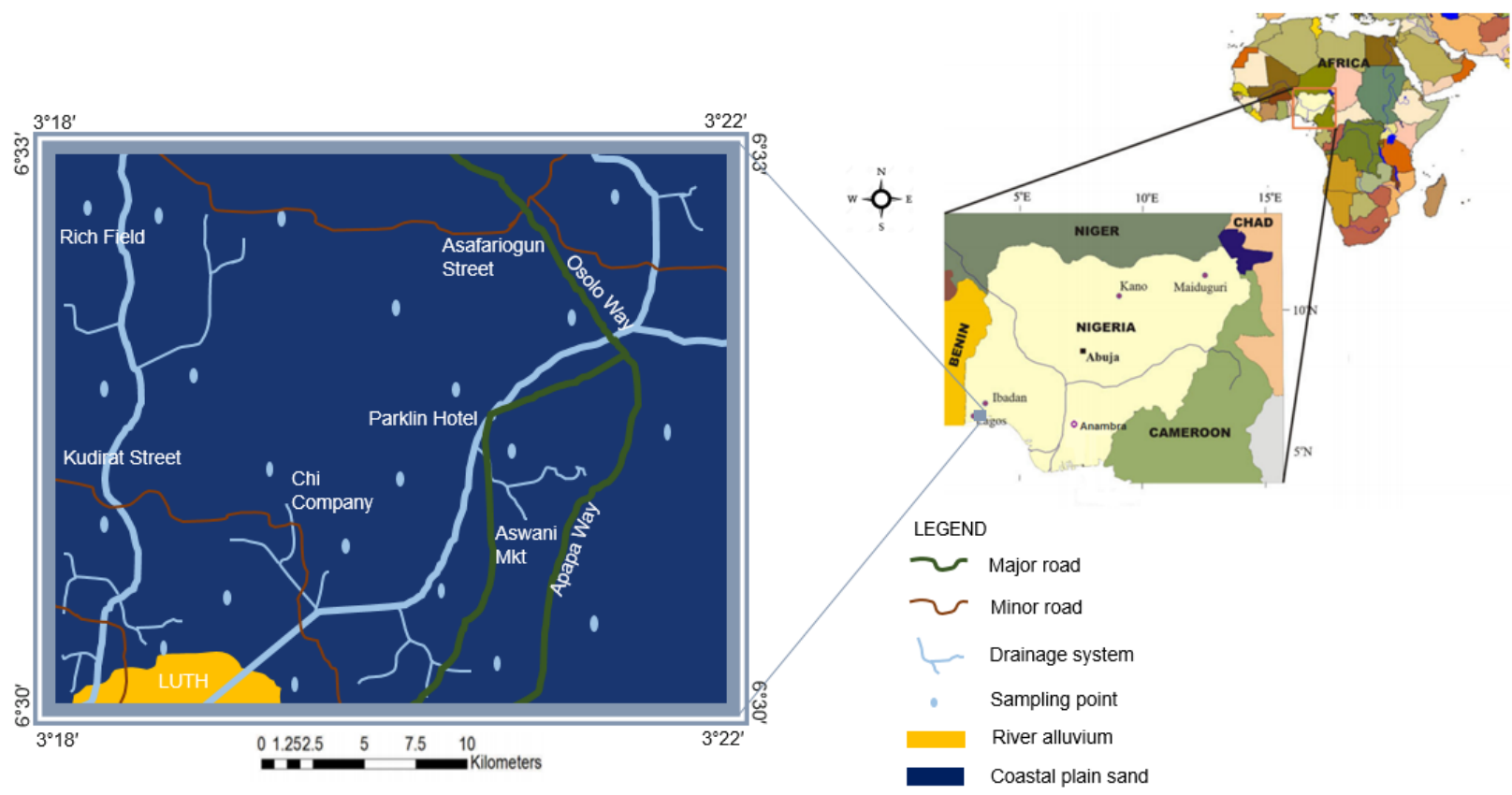

Figure 1: Geologic map of the study area. 
control samples were randomly collected across the Ajao industrial area and its environs. The soil samples were taken between depths of 0-0.5 $\mathrm{m}$ with hand shovel and disposable hand gloves, carefully bagged in polyethylene sacks, and legibly labelled. The following heavy metals ( $\mathrm{Fe}, \mathrm{Zn}, \mathrm{Pb}, \mathrm{Cd}$, $\mathrm{Mn}, \mathrm{Cu}, \mathrm{Cr}$, and $\mathrm{Ni}$ ) in the soil samples were analysed in the laboratory using the specific hollow cathode lamp at a specific wavelength. $5 \mathrm{~g}$ of soil samples in a clean porcelain crucible were heated over a hot plate to ignite. In order to completely oxidize the organic matter, the residue was heated in a muffle furnace at $550{ }^{\circ} \mathrm{C}$. The residue left was dissolved in a few drops of aqua regia and then diluted with distilled water [21]. The resulting mixture was then filtered, rinsed, and then aspirated into the flame of the atomic absorption spectrophotometer (AAS) Perkin Elmer Analyst 200, using air acetylene flame for the metal analysis against standard metal solutions. All the analytical procedures described in this study followed the recommendations of American Public Health Association [38].

\section{Heavy metal evaluation of the soil quality}

Indexical Tools: Soil contaminant assessment indices are indicators used to assess the presence and intensity of anthropogenic contaminant deposition on soils. In this study, the following pollution assessment indices were employed; contamination Factor (CF), Pollution Load Index (PLI), Modified Contamination Degree (mCD), Geo-accumulation Index (Igeo), ecological risk factor $\left(\sum \mathbf{R I}\right)$ and Nemerow Integrated Pollution Index (NIPI). These indices were used to assess the heavy metals tested in the soil samples collected from the study area (Table 1). Department of Petroleum Resource (DPR) [39], allowable concentration of heavy metals in the soil was used as the background value (Table 1).

Contamination Factor (CF): The contamination factor (CF) was used in the evaluation of the soil samples to indicate the degree of pollution for each heavy metal in a soil samples [21]. The CF value could fall into either of the levels of contamination where $\mathrm{CF}<1$ refers to low contamination, 1 $\leq \mathrm{CF}<3$ indicates moderate contamination, $3 \leq \mathrm{CF} \leq 6$ means considerable high contamination, and CF $>6$ refers to very high contamination $[21,40]$. CF is calculated as follows;

\section{$\mathrm{CF}=$ Cmetal/Cbackground}

where

\section{Cmetal $=$ The total metal concentration}

Cbackground = Average background value of the element in sediment.

Geochemical Accumulation Index (I-geo): The I-geo enables the assessment of contamination by comparing the present heavy metals concentrations and the original pre-industrial concentrations in the soils. Geochemical accumulation index (I-geo) consists of five classes ranging from unpolluted to extremely polluted: I-geo $<1$ unpolluted, $1 \leq$ I-geo $<2$ indicates low pollution, $3 \leq$ I-geo $<4$ moderately polluted, $4 \leq$ Igeo $<5$ strongly polluted, and I-geo $<5$ is extremely polluted Muller [40] and Martin and Meybeck [41].
I-geo is calculated as;

1-geo $=\log _{2}(\mathrm{Cn} / 1.5 \mathrm{Bn})$

Where $\mathrm{Cn}$ is the concentration of the metal pollutant

$\mathrm{Bn}$ is the geochemical background concentration of the pollutant in sediment, and

1.5 is the background matrix correction factor due to lithogenic effect.

Pollution Load Index (PLI): The PLI gives a generalized assessment on the level of soil contamination. The PLI is obtained using Thomlinson, et al. [42] with the following classification scheme; PLI = 0 (background concentration), 0 $<\mathrm{PLI} \leq 1$ (unpolluted), $1<\mathrm{PLI} \leq 2$ (moderately to unpolluted), $2<\mathrm{PLI} \leq 3$ (moderately polluted), $3<\mathrm{PLI} \leq 4$ (moderately to highly polluted and $4<\mathrm{PLI} \leq 5$ (highly polluted) and $\geq 5$ (very highly polluted).

$\mathrm{PLI}$ is calculated as;

$\mathrm{PLI}=\left(\mathrm{CF}_{1} \times \mathrm{CF}_{2} \times \mathrm{CF}_{3} \ldots \ldots . . . \mathrm{CF}_{\mathrm{n}}\right)^{1 / \mathrm{n}}$

Where, $\mathrm{CF}=$ Contamination Factor; and $\mathrm{n}=$ Number of Metals

\section{Modified Contamination Degree $\left(\mathrm{mC}_{\mathrm{d}}\right)$}

The $\mathrm{mC}_{d}$ is an empirical assessment of the overall degree of contamination by pollutants in an area. The $\mathrm{mC}_{d}$ was calculated as defined by Hakanson [28] as follows:

$$
\mathrm{mC}_{\mathrm{d}}=\sum_{i=1}^{i=n} \mathrm{CF} / \mathrm{n}
$$

Where $\mathrm{Cf}=$ Contamination Factor, $\mathrm{n}=$ Number of Analyzed Metals, and $i$ is $i$ th metal.

$\mathrm{mC}_{\mathrm{d}}$ classification scheme is as follows; $\mathrm{mC}_{\mathrm{d}}<1.5$ (very low degree of contamination), $\leq 1.5 \mathrm{mC}_{\mathrm{d}}<2$ (low degree of contamination), $\leq 2 \mathrm{mC}_{\mathrm{d}}<4$ (moderate degree of contamination), $\leq 4 \mathrm{mC}_{\mathrm{d}}<8$ (high degree of contamination), $\leq 8 \mathrm{mC}_{\mathrm{d}}<16$ (very high degree of contamination), $\leq 16 \mathrm{mC}_{\mathrm{d}}$ $<32$ (extremely high degree of contamination) and $\geq 32 \mathrm{mC}_{\mathrm{d}}$ (ultrahigh degree of contamination).

\section{Ecological Risk Index $\left(\sum \mathbf{R I}\right)$}

To evaluate the ecological risk associated with the presence of heavy metals present in the soil, ecological risk index of some heavy metals were calculated. Ecological risk factor $(E r)$ for a given contaminant was calculated as suggested by Håkanson [28] and Ukah, et al. [18]

$$
\sum \mathbf{R I}=\sum T_{i} x C F
$$

$\mathrm{RI}=$ The potential ecological risk factor of each heavy metal; $T_{i}=$ The toxic-response factor of heavy metal;

$\mathrm{CF}=$ Contamination Factors. The toxic-response factor of heavy metals is given as thus: $\mathrm{Cd}=30$; $\mathrm{As}=10$; $\mathrm{Co}, \mathrm{Cu}, \mathrm{Ni}$ and $\mathrm{Pb}=5 ; \mathrm{Cr}=2$, and $\mathrm{Zn}$ and $\mathrm{Mn}=1[43,44]$.

The following classification schemes were used to describe the risk factor: $E r<40$, low potential ecological risk; $40 \leq E r<80$, moderate potential ecological risk; $80 \leq E r<160$, considerable potential ecological risk; $160 \leq E r<320$, high potential ecological risk; and $E r \geq 320$, very high ecological risk. 
Citation: Ukah BU, Igwe O, Ubido OE (2021) Indexical Evaluation of Heavy Metal Concentrations in Soil around Industrial Area of Ajao-Estate Lagos Nigeria. J Soil Water Sci 5(1):184-192

Table 1: Heavy metal results from the soil samples and calculated I-geo, CF and NIPI.

\begin{tabular}{|c|c|c|c|c|c|c|c|c|c|c|c|}
\hline Source & $\mathrm{Zn}(\mathrm{mg} / \mathrm{kg})$ & $\mathrm{Cu}(\mathrm{mg} / \mathrm{kg})$ & $\begin{array}{l}\mathrm{Cd}(\mathrm{mg} / \\
\mathrm{kg})\end{array}$ & $\mathrm{Pb}(\mathrm{mg} / \mathrm{kg})$ & $\begin{array}{l}\mathrm{Fe}(\mathrm{mg} / \\
\mathrm{kg})\end{array}$ & $\begin{array}{l}\mathrm{Ni}(\mathrm{mg} / \\
\mathrm{kg})\end{array}$ & $\begin{array}{l}\mathrm{Mn}(\mathrm{mg} / \\
\mathrm{kg})\end{array}$ & $\mathrm{Cr}(\mathrm{mg} / \mathrm{kg})$ & PI & Plave & NIPI \\
\hline SS 1 & 1.890 & 0.120 & 0.002 & - & 0.080 & - & 0.050 & - & 2.142 & 0.26775 & 1.349776 \\
\hline SS 2 & 1.980 & 0.150 & 0.002 & - & 0.080 & - & 0.030 & - & 2.242 & 0.28025 & 1.414026 \\
\hline SS 3 & 20.410 & 7.810 & 1.160 & 0.005 & 9.110 & 0.008 & 1.280 & 0.020 & 39.803 & 4.975375 & 14.85467 \\
\hline SS 4 & 1.290 & 0.070 & 1.020 & - & 0.040 & - & 0.020 & - & 2.44 & 0.305 & 0.937317 \\
\hline SS 5 & 1.350 & 0.080 & - & - & 0.050 & - & 0.030 & - & 1.51 & 0.18875 & 0.963879 \\
\hline SS 6 & 1.063 & 0.050 & - & - & 0.020 & - & 0.020 & - & 1.153 & 0.144125 & 0.758532 \\
\hline SS 7 & 9.250 & 2.860 & 0.003 & 0.001 & 0.330 & 0.002 & 0.037 & 0.008 & 12.491 & 1.561375 & 6.633264 \\
\hline SS 8 & 0.590 & 0.020 & - & - & 0.020 & - & 0.010 & - & 0.64 & 0.08 & 0.421011 \\
\hline SS 9 & 1.060 & 0.080 & - & - & 0.030 & - & 0.030 & - & 1.2 & 0.15 & 0.757001 \\
\hline SS 10 & 1.170 & 0.120 & - & - & 0.030 & - & 0.040 & - & 1.36 & 0.17 & 0.836002 \\
\hline SS 11 & 0.740 & 0.030 & - & - & 0.030 & - & 0.040 & - & 0.84 & 0.105 & 0.5285 \\
\hline SS 12 & 0.310 & 0.020 & - & - & 0.010 & - & - & - & 0.34 & 0.0425 & 0.221254 \\
\hline SS 13 & 0.490 & 0.060 & - & - & 0.010 & - & 0.002 & - & 0.562 & 0.07025 & 0.350025 \\
\hline SS 14 & 1.600 & 0.011 & - & - & 0.060 & - & 0.005 & - & 1.676 & 0.2095 & 1.141028 \\
\hline SS 15 & 0.820 & 0.040 & - & - & 0.040 & - & 0.007 & - & 0.907 & 0.113375 & 0.585343 \\
\hline SS Igeo & -3.74591 & -3.69395 & -1.83085 & -11.0069 & -8.10749 & -9.75012 & -7.57682 & -9.79468 & & & \\
\hline CF & 0.301458904 & 0.32002778 & 2.73375 & 7.05882E-05 & 0.001988 & 0.0002857 & 0.0036636 & 0.00028 & & & \\
\hline$\sum R I$ & 0.301459 & 1.600139 & 82.0125 & 0.000353 & NOTA & 0.001429 & 0.003664 & 0.00056 & & & \\
\hline Range & $\begin{array}{l}0.310- \\
20.410\end{array}$ & $\begin{array}{l}0.011- \\
7.810\end{array}$ & $\begin{array}{l}0.000- \\
1.160\end{array}$ & $\begin{array}{l}0.000- \\
0.005\end{array}$ & $\begin{array}{l}0.010- \\
9.110\end{array}$ & $\begin{array}{l}0.000- \\
0.008\end{array}$ & $\begin{array}{l}0.000- \\
1.280\end{array}$ & $\begin{array}{l}0.000- \\
0.020\end{array}$ & & & \\
\hline Mean & 2.9342 & 0.7681 & 0.1458 & 0.0004 & 0.6627 & 0.0007 & 0.1067 & 0.0019 & & & \\
\hline Std. Dev. & 5.2919 & 2.0770 & 0.3843 & 0.0013 & 2.3382 & 0.0021 & 0.3249 & 0.0054 & & & \\
\hline CS16 & 1.840 & 0.081 & 0.001 & - & 0.040 & 0.003 & 0.010 & - & 1.975 & 0.246875 & 1.312735 \\
\hline CS17 & 5.960 & 2.023 & - & 0.001 & 0.040 & - & 0.008 & 0.006 & 8.038 & 1.00475 & 4.273823 \\
\hline CS18 & 8.650 & 0.040 & 0.001 & 0.020 & 1.720 & 0.010 & 1.020 & - & 11.461 & 1.432625 & 6.199795 \\
\hline CS19 & 2.480 & 1.440 & 0.080 & 0.054 & 0.020 & - & 0.310 & - & 4.384 & 0.548 & 1.795927 \\
\hline CS20 & 11.570 & 4.710 & 1.080 & 0.003 & 8.540 & 0.005 & 0.720 & 0.250 & 26.878 & 3.35975 & 8.519179 \\
\hline CS21 & 1.350 & 0.080 & 0.000 & 0.000 & 0.050 & 0.000 & 0.030 & 0.000 & 1.51 & 0.18875 & 0.963879 \\
\hline CS Igeo & -3.23097 & -3.17522 & -1.58425 & -7.98313 & -7.27152 & -8.48608 & -6.54584 & -7.09201 & & & \\
\hline CF & 0.218150685 & 0.23261111 & 1.4525 & 0.000917647 & 0.002082 & 0.0005143 & 0.0048009 & 0.00256 & & & \\
\hline$\sum R I$ & 0.218151 & 1.163056 & 43.575 & 0.004588 & NOTA & 0.002571 & 0.004801 & 0.00512 & & & \\
\hline Range & $\begin{array}{l}1.840- \\
11.570\end{array}$ & $\begin{array}{l}0.040- \\
4.710\end{array}$ & $\begin{array}{l}0.000- \\
1.080\end{array}$ & $000-0.054$ & $\begin{array}{l}0.02- \\
8.54\end{array}$ & $000-.010$ & $\begin{array}{l}0.008- \\
1.020\end{array}$ & $\begin{array}{l}000- \\
0.250\end{array}$ & & & \\
\hline Mean & 5.308333 & 1.395667 & 0.2324 & 0.0156 & 1.735 & 0.0045 & 0.349667 & 0.085333 & & & \\
\hline Std Dev. & 4.159257 & 1.826334 & 0.475067 & 0.022963 & 3.401022 & 0.004203 & 0.429503 & 0.142637 & & & \\
\hline DPR & 146.000 & 36.000 & 0.800 & 85.000 & 5000.000 & 35.000 & 437.000 & 100.00 & & & \\
\hline
\end{tabular}

SS = Soil Sample; CS = Control Sample; STD Dev = Standard Deviation.

\section{Nemerow Integrated Pollution Index (NIPI)}

The NIPI was also employed to assess the overall pollution integrity of the area. NIPI was calculated as defined by Nemerow [44] as:

$$
N I P I=\sqrt{\left[(\text { PIave })^{2}+(P I \mathrm{max})^{2}\right] / 2}
$$

Where Plave $=$ Average concentration of all pollution indices considered, and PImax = Maximum pollution index.

Pollution index $(\mathrm{PI})$ is calculated as $(\mathrm{PI})=\mathrm{C}_{\mathrm{s}} / \mathrm{C}_{\mathrm{b}}=$ The concentration of heavy metals in the sample; $C_{b}=$ The corresponding background values. The NIPI classification scheme is as NIPI $=\leq 0.7$ (safe), $>0.7 \mathrm{NIPI} \leq 1$ (precaution), $>1$ $\mathrm{NIPI} \leq 2$ (slightly polluted), $>2 \mathrm{NIPI} \leq 3$ (moderately polluted) and $>3$ (heavily polluted).

\section{Statistical Analysis}

In this research, SPSS (Statistical Package for the Social Sciences) for Windows, version 23.0 (SPSS Inc, USA) was used for descriptive analysis of data.

\section{The descriptive analysis}

This describes the basic features of the data in the study. It include mean, standard deviation (SD), minimum and maximum concentration values (Range) of different metal element concentrations were used to indicate indirectly the activeness of the selected element in the sampling Site. A multivariate correlation of heavy metals tested in the soil sample were carried using Pearson correlation coefficients at two-tailed test of 0.02 and 0.05 levels of significance with the 
aid of SPSS. In this study, the higher the value is, the stronger the correlation of the heavy metals to each other $[45,46]$. Here, correlation coefficients $>0.7$ is considered as strong correlation, $<0.7 \geq 0.5$ moderate while $<0.5$ is considered as weak correlation. According to Ukah, et al [21], positive correlations always indicate that source of the elements is the same and vice versa.

\section{Result and Discussion}

Based on the kind of anthropogenic activities going on in the study eight (8) heavy metals ( $\mathrm{Fe}, \mathrm{Zn}, \mathrm{Pb}, \mathrm{Cd}, \mathrm{Mn}$, $\mathrm{Cu}, \mathrm{Cr}$, and $\mathrm{Ni}$ ) were tested in the soil samples. The results were summarized in (Table 1). Comparing the results in Table 1 with DPR [39] permissible standard for heavy metal concentration in the soil, all the metals are within the standard except Cd concentration in SS3 (1.160), SS4 (1.020) and CS20 (1.080). SS3 is the wastewater dislodging point for food/wine producing industrial in the study area, followed by SS4 in term of nearness probably; this might be the reason for very high concentration of all the heavy metals in them. $\mathrm{Cd}$ being a transitional element has been found to possess biological toxicity if it is absorb by crop and animals [47]. The geology of the area has been described to be dominantly alluvial sands. Such deposits are not naturally rich in heavy metals but are coarse, porous and permeable enough to facilitate the contamination of shallow groundwater [48]. This suggests that there are no geologically rich natural deposits in the heavy metals analysed $[21,48]$. Considering the role of geology (parent rock) in defining the environmental chemical ions hence; higher concentration of some of the heavy metals in the control than that of the study area. Moreover, the soil in study area is prone to constant hydraulic loading of industrial wastewater unlike the control and this might be the reason for higher concentration of these heavy metals in wastewater dislodging point (SS3) and the nearest sampling point (SS4) than any other sampling points [21]. Thus, the origins of the accumulated heavy metals in the soils are linked to anthropogenic sources.

\section{Statistical description of the heavy metals in the soil samples}

The descriptive analysis: Statistically (Table 1), Zn averaged $2.9342 \mathrm{mg} / \mathrm{kg}$ with a range of $0.310-20.410 \mathrm{mg} / \mathrm{kg}$. While in control, the average is $6.1000 \mathrm{mg} / \mathrm{kg}$ and it ranged from 1.84 to $11.57 \mathrm{mg} / \mathrm{kg}$. The standard deviation for the sample is 5.2919 and 4.11385 for the control. The concentrations of both samples are within the DPR standard. Foe $\mathrm{Cu}$; the mean value here is $0.7681 \mathrm{mg} / \mathrm{kg}$, range of $0.011-7.810 \mathrm{mg} / \mathrm{kg}$ and the standard deviation of 2.0772, while in control, the mean is 1.65880 , varied from $0.04-4.71 \mathrm{mg} / \mathrm{kg}$ with standard deviation of 1.910517. The mean value of $\mathrm{Cd}$ is $0.1458 \mathrm{mg} /$ $\mathrm{kg}$, and varied from $0.000-1.160 \mathrm{mg} / \mathrm{kg}$. In control, the mean value of $0.212456 \mathrm{mg} / \mathrm{kg}$ with the range of $0.00-1.080 \mathrm{mg} /$ $\mathrm{kg}$ were obtained. However, the standard deviation of sample is 0.3843 and in control, 0.475067 . Cd being a transitional element has been found to possess biological toxicity if it is absorb by crop and animals [47]. Here, the mean value of Fe is $0.6627 \mathrm{mg} / \mathrm{kg}$ with the range of $0.010-9.110 \mathrm{mg} / \mathrm{kg}$ while in control the mean value is $2.0720 \mathrm{mg} / \mathrm{kg}$ and the range is 0.02 $8.54 \mathrm{mg} / \mathrm{kg}$. 2.3382 for the standard deviation of the samples and 3.68876 for the control. $\mathrm{Mn}$ had an average value of $0.1067 \mathrm{mg} / \mathrm{kg}$, varied from $0.000-1.280 \mathrm{mg} / \mathrm{kg}$ and standard deviation of 0.3249 . While in control, it averaged $0.41360 / \mathrm{kg}$ and varied from $0.008-1.020 \mathrm{mg} / \mathrm{Kg}$. with standard deviation of 0.447141 . $\mathrm{Pb}$ averaged 0.0004 and ranged $0.000-0.005$ with standard deviation of 0.0013 but in averaged 0.01560 , ranged from $000-0.054$ and standard deviation of 0.022963 for the control. $\mathrm{Ni}$ averaged 0.0007 and ranged from 0.000 0.008 , varied in control from 0.000 to 0.01 with mean value of $0.00360 \mathrm{mg} / \mathrm{kg}$. The standard deviation is 0.0021 for the samples and 0.004159 for the control respectively. The mean value of $\mathrm{Cr}$ is 0.0019 with the range of $0.000-0.020$ and standard deviation of 0.0054 while in the control, the mean is $.05120 \mathrm{mg} / \mathrm{kg}$, range of 0.000 to $0.25 \mathrm{mg} / \mathrm{Kg}$ and standard deviation of 0.111163 . The heavy metal concentrations in the soil samples (Table 1) where compared with the allowable concentration stipulated by department of petroleum resources [39], it was discovered that the concentration of all the elements in both soils meet up the standard except $\mathrm{Cd}$.

Correlation analysis of the heavy metals in the soil: From the correlation analysis result in Table $2, \mathrm{~Pb}$ has no significant correlation with other heavy metals in the soil samples. This suggest that $\mathrm{Pb}$ although found in few soil samples has a different anthropogenic sources from others. Sources $\mathrm{Pb}$ in the soil samples may be attributed to automobile mechanic workshops, industrial plants, $\mathrm{Pb}$-acid batteries, effluents from textile tanning industries and air conditioning coolants [51]. Zn correlates positively and strongly with $\mathrm{Cu}(0.934), \mathrm{Fe}$ (0.870), $\mathrm{Ni}(0.801)$ and $\mathrm{Mn}(0.863)$ and also moderately with $\mathrm{Cd}(0.657)$, at a 2-tailed significant of 0.01 but weakly with $\mathrm{Cr}$

Table 2: Statistical correlation of the heavy metals.

\begin{tabular}{|l|l|l|l|l|l|l|l|l|}
\hline Correlations & \multicolumn{9}{|c|}{ ( } & Zn & Cu & Cd & Pb & Fe & Ni & Mn & \\
\hline & 1 & & & & & & \\
\hline $\mathrm{Zn}$ & $0.934^{* *}$ & 1 & & & & & \\
\hline $\mathrm{Cd}$ & $0.657^{* *}$ & $0.724^{* *}$ & 1 & & & & \\
\hline $\mathrm{Pb}$ & 0.126 & 0.117 & 0.000 & 1 & & & \\
\hline $\mathrm{Fe}$ & $0.870^{* *}$ & $0.890^{* *}$ & $0.808^{* *}$ & 0.040 & 1 & & \\
\hline $\mathrm{Ni}$ & $0.801^{* *}$ & $0.578^{* *}$ & $0.459^{*}$ & 0.206 & $0.703^{* *}$ & 1 & \\
\hline $\mathrm{Mn}$ & $0.863^{* *}$ & $0.728^{* *}$ & $0.607^{* *}$ & 0.346 & $0.833^{* *}$ & $0.919^{* *}$ & 1 & \\
\hline $\mathrm{Cr}$ & $0.437^{*}$ & $0.509^{*}$ & $0.586^{* *}$ & -0.020 & $0.712^{* *}$ & 0.336 & 0.394 & 1 \\
\hline
\end{tabular}

** Correlation is significant at the 0.01 level (2-tailed); * Correlation is significant at the 0.05 level (2-tailed). 
(0.437) at a 0.05 significant level. Cu correlate strongly and positively at 2-tailed significant level of 0.01 with $\mathrm{Cd}(0.724)$, Fe (0.890), $\mathrm{Mn}(0.728)$ and moderately with $\mathrm{Ni}(0.578)$ and moderately with $\mathrm{Cr}(0.509)$ at 0.05 level of significant. $\mathrm{Cd}$ correlates positively and strongly at 2-tailed level of 0.01 levels with $\mathrm{Fe}$ (0.808), moderately with $\mathrm{Mn}$ (0.607). $\mathrm{Cr}(0.586)$ and weakly with $\mathrm{Ni}(0.459)$ at 2-tailed significant level of 0.05 . At a 2-tailed significant level 0.01, Fe correlates positively strongly with $\mathrm{Zn}$ (0.870), $\mathrm{Cu}$ (0.890), Cd (0.808), Ni (0.703), $\mathrm{Mn}(0.833)$ and $\mathrm{Cr}(0.712)$. Ni correlates strongly with $\mathrm{Mn}$ (0.919) at 2-tailed significant level of 0.01. Significant strong to medium positive correlation existing between these heavy metal presented in Table 3 suggests that these metals have the same anthropogenic origin such as industrial wastewater, e-waste, $\mathrm{Ni} / \mathrm{Cd}$ batteries, paints etc $[45,52]$.

Soil indexical evaluation models: Soil contaminant assessment indices are indicators used to assess the presence and intensity of anthropogenic contaminant deposition on soils. In this study, the following pollution assessment indices were employed; contamination Factor (CF), Pollution Load Index (PLI), Modified Contamination Degree (mCD), Geoaccumulation Index (Igeo) and Nemerow Integrated Pollution Index (NIPI). These indices were used to assess the heavy metals tested in the soil samples collected from the study area (Table 1). Department of Petroleum Resource (DPR) [39] standard for allowable heavy metals concentration in the soil in Nigeria was used as the background value for this study.

Igeo gives insight to the extent of heavy metal enrichment in the soil samples studied, According to Muller [40] and Martin and Meybeck [42] I-geo classification scheme for soil pollution, the 1-geo calculated for heavy metal concentration in the soil sample, suggest that all the samples are unpolluted since the soil samples are within I-geo classification scheme of less than $1(<1)$ (Table 1$)$.

The contamination factor indicates the degree of pollution for each heavy metal in all the soil samples. The CF of the heavy metals ranged from 7.05882E-05 (Pb) to $2.73375(\mathrm{Cd})$ in the soil samples while in control samples, CF ranged from $0.0005143(\mathrm{Ni})$ to $1.4525(\mathrm{Cd})$ (Table 1). Cd falls in the range of moderate contamination $(1 \leq \mathrm{CF}<3)$. Higher $\mathrm{CF}$ value resulting from $\mathrm{Cd}$ in both samples proved that $\mathrm{Cd}$ has the highest impact in the soil especially the industrial soil. Heavy metal concentrations in both soil samples fall within low to moderate contamination based Cf classification scheme $[21,43]$. This observation indicates that the inhabitants of this industrial area are more likely to be exposed to environmental risks due to $\mathrm{Cd}$ enrichment in the soil.

Following the $\sum R I$ classification scheme by Hakason [28], all the heavy metals analysed in this study pose low ecological risks except for Cd (82.0125) which showed considerable potential ecological risk since it falls within $80 \leq E r<160$, considerable potential ecological risk while Cd (43.575) in the control falls within moderate potential ecological risk, $40 \leq \mathrm{Er}^{i}<80$ (Table 1). This suggests among all the heavy metals analysed, $\mathrm{Cd}$ pose highest danger to the ecosystem, and threats to both plants and animals [49] around the study area
NIPI gives a better and overall understanding of the heavy metals pollution in an individual sample, rather than revealing a general pollution degree of each heavy metal like in the case of geo accumulation index (I-geo). In this study, NIPI model further assess the cumulative index values and overall impact of the heavy metal pollutants in each of the soil samples (Table 1). Based on NIPI classification scheme by Nemerow [29], samples SS8, SS9, SS11-SS13 and SS14 were safe, SS4,-SS6 and SS10 requires precaution while dealing on the soil samples. Samples SS1, SS2 and SS14 were slightly polluted however samples SS3 and SS7 were heavily polluted. In the control, one sample (CS21) requires precaution, three of the six were slightly polluted while two where heavily polluted but not as heavy as that observed in the wastewater dislodging point (Table 1). This suggests that the inhabitant of this study especially those around SS3 and SS7 are under severe pollution threat.

In this study, mCd provides the sum of the contamination factor of all the elements analysed in each of the soil samples collected (Table 2). Irrespective of the variation in the empirical result from $\mathrm{mCd}$ in the soil samples, all the samples within the range $(0.000335-0.226492)$ of very low degree of contamination [28].

Pollution severity and its variation along the sample locations were determined with the use of pollution load index (PLI). This index is a quick tool in order to compare the pollution status of different places. It also provides the degree of heavy metal pollution with respect to all the heavy metals present in the soil sample [50] The PLI result shows that sample SS3 (0.005309), SS7 (0.000524) and CS20 (0.005152) show little value whereas the rest of the samples remain insignificant (Table 3), indicating that the samples within unpolluted range in the PLI classification scheme.

\section{Conclusions}

The industrial soils from Ajao urban area, Lagos, Nigeria were investigated with the aim of unravelling the indexical characteristics of heavy metals pollution status, possible pollution sources and impact on ecological. The following conclusions were drawn from the findings of this research:

All the metals are within the standard except $\mathrm{Cd}$ concentration in SS3, SS4 and CS20. Pb has no significant correlation with other heavy metals in the soil samples. This suggest that $\mathrm{Pb}$ although found in few soil samples has a different anthropogenic sources from others. While for other heavy metals strong to medium positive correlation exist between these heavy metals at 2-tailed significant levels of 0.01 and 0.05 suggests that these metals have the same anthropogenic origin.

The 1-geo calculated for heavy metal concentration in the soil sample, suggest that all the samples are unpolluted since the soil samples are within I-geo classification scheme of less than $1(<1)$. CF of the heavy metals was in the range of low contamination except $\mathrm{Cd}$ that showed moderate contamination The $\sum R I$ of all the heavy metals analysed in this study pose low ecological risks except for $\mathrm{Cd}$ (82.0125) which showed considerable potential ecological risk since it falls within $80 \leq E r^{i}<160$, considerable potential 
Citation: Ukah BU, Igwe O, Ubido OE (2021) Indexical Evaluation of Heavy Metal Concentrations in Soil around Industrial Area of Ajao-Estate Lagos Nigeria. J Soil Water Sci 5(1):184-192

Table 3: Calculated $\mathrm{mCd}$ and PLI of the heavy metals in the samples.

\begin{tabular}{|c|c|c|c|c|c|c|c|c|c|c|}
\hline Source & CF Zn & $\mathrm{CF} \mathrm{Cu}$ & CF Cd & CF Pb & CF Fe & CF Ni & CF Mn & CF Cr & MCd & PLI \\
\hline SS1 & 0.012945 & 0.003333 & 0.0025 & 0 & 0.000016 & 0 & 0.000114 & 0 & 0.002364 & 0 \\
\hline SS 2 & 0.013562 & 0.004167 & 0.0025 & 0 & 0.000016 & 0 & $6.86 \mathrm{E}-05$ & 0 & 0.002539 & 0 \\
\hline SS 3 & 0.139795 & 0.216944 & 1.45 & $5.88 \mathrm{E}-05$ & 0.001822 & 0.000229 & 0.002929 & 0.0002 & 0.226497 & 0.005309 \\
\hline SS 4 & 0.008836 & 0.001944 & 1.275 & 0 & 0.000008 & 0 & $4.58 \mathrm{E}-05$ & 0 & 0.160729 & 0 \\
\hline SS 5 & 0.009247 & 0.002222 & 0 & 0 & 0.00001 & 0 & $6.86 \mathrm{E}-05$ & 0 & 0.001443 & 0 \\
\hline SS 6 & 0.007281 & 0.001389 & 0 & 0 & 0.000004 & 0 & $4.58 \mathrm{E}-05$ & 0 & 0.00109 & 0 \\
\hline SS 7 & 0.063356 & 0.079444 & 0.00375 & 1.18E-05 & 0.000066 & 5.71E-05 & 8.47E-05 & 0.00008 & 0.018356 & 0.000524 \\
\hline SS 8 & 0.004041 & 0.000556 & 0 & 0 & 0.000004 & 0 & 2.29E-05 & 0 & 0.000578 & 0 \\
\hline SS 9 & 0.00726 & 0.002222 & 0 & 0 & 0.000006 & 0 & $6.86 \mathrm{E}-05$ & 0 & 0.001195 & 0 \\
\hline SS 10 & 0.008014 & 0.003333 & 0 & 0 & 0.000006 & 0 & $9.15 \mathrm{E}-05$ & 0 & 0.001431 & 0 \\
\hline SS 11 & 0.005068 & 0.000833 & 0 & 0 & 0.000006 & 0 & 9.15E-05 & 0 & 0.00075 & 0 \\
\hline SS 12 & 0.002123 & 0.000556 & 0 & 0 & 0.000002 & 0 & 0 & 0 & 0.000335 & 0 \\
\hline SS 13 & 0.003356 & 0.001667 & 0 & 0 & 0.000002 & 0 & 4.58E-06 & 0 & 0.000629 & 0 \\
\hline SS 14 & 0.010959 & 0.000306 & 0 & 0 & 0.000012 & 0 & 1.14E-05 & 0 & 0.001411 & 0 \\
\hline SS 15 & 0.005616 & 0.001111 & 0 & 0 & 0.000008 & 0 & $1.6 \mathrm{E}-05$ & 0 & 0.000844 & 0 \\
\hline CS16 & 0.012603 & 0.00225 & 0.00125 & 0 & 0.000008 & 8.57E-05 & 2.29E-05 & 0 & 0.002027 & 0 \\
\hline CS17 & 0.040822 & 0.056194 & 0 & $1.18 \mathrm{E}-05$ & 0.000008 & 0 & $1.83 \mathrm{E}-05$ & 0.00006 & 0.012139 & 0 \\
\hline CS18 & 0.059247 & 0.001111 & 0.00125 & 0.000235 & 0.000344 & 0.000286 & 0.002334 & 0 & 0.008101 & 0 \\
\hline CS19 & 0.016986 & 0.04 & 0.1 & 0.000635 & 0.000004 & 0 & 0.000709 & 0 & 0.019792 & 0 \\
\hline CS2O & 0.079247 & 0.130833 & 1.35 & $3.53 \mathrm{E}-05$ & 0.001708 & 0.000143 & 0.001648 & 0.0025 & 0.195764 & 0.005152 \\
\hline CS21 & 0.009247 & 0.002222 & 0 & 0 & 0.00001 & 0 & $6.86 \mathrm{E}-05$ & 0 & 0.001443 & 0 \\
\hline DPR & 146.000 & 36.000 & 0.800 & 85.000 & 5000.000 & 35.000 & 437.000 & 100.00 & & \\
\hline
\end{tabular}

ecological risk while $\mathrm{Cd}$ (43.575) in the control falls within moderate potential ecological risk, $40 \leq E r<80$. Based on NIPI classification scheme, samples SS8, SS9, SS11-SS13 and SS14 were safe, SS4,-SS6 and SS10 requires precaution while dealing on the soil samples. Samples SS1, SS2 and SS14 were slightly polluted however samples SS3 and SS7 were heavily polluted. In the control, one sample (CS21) requires precaution, three of the six were slightly polluted while two where heavily polluted but not as heavy that observed in the wastewater dislodging point (SS3). For $\mathrm{mCd}$, all the samples within the range (0.000335-0.226492) of very low degree of contamination. The PLI result shows that sample SS3 (0.005309), SS7 (0.000524) and CS20 (0.005152) show little value whereas the rest of the samples remain insignificant, indicating that the samples were within unpolluted range in the PLI classification scheme.

\section{Conflict of Interest Statement}

The authors hereby declare that there is no competing interest regarding this paper.

\section{References}

1. Glanz A (1995) Saving our soil: Solutions for sustaining earth's vital resource. In: Johnson Books, Boulder, Colo, USA.

2. Eswaran H, Lal R, Reich PF (2001) Land degradation: An overview. In: EM Bridges, ID Hannam, LR Oldeman (Edn) Response to land degradation, Science Publishers, Enfield, NH, USA pp. 20-35.

3. Girmay G, Singh BR, Mitiku H, et al. (2008) Carbon stocks in Ethiopian soils in relation to land use and soil management. Land Degradation and Development 19: 351-367.

4. Kabata-Pendias A, Mukherjee AB (2007) Trace elements from soil to human. Springer Berlin Heidelberg, New York, 550.
5. Proust D, Fontaine C, Dauger N (2013) Impacts of weathering and clay mineralogy on heavy metals sorption in sludgeamended soils. Catena 101: 188-196.

6. Suresh KR, Nagesh MA (2015) Experimental studies on effect of water and soil quality on crop yield. Inter Conf on Water Reso, Coastal and Ocean Eng. (ICWRCOE). Aquatic Procedia 4: 1235-1242.

7. Yonglong LU, Song S, Wang R, et al. (2015) Impacts of soil and water pollution on food safety and health risks in China. Environ Int 77: 5-15.

8. Salman SA, Zeid SA, Seleem EM, et al. (2016a) Assessment of soil pollution with heavy metals in Orabi farms, El-Obour city, Egypt. In: The $54^{\text {th }}$ annual scientific meeting at the Egyptian mineral resources authority, GSE.

9. Krishna AK, Mohan KR (2016) Distribution, correction, ecological and health risk assessment of heavy metal contamination in surface soils around an industrial area, Hyderabad, India. Environ Earth Sci 75: 411

10. Yadav IC, Devi NL (2017) Pesticides classification and its impact on human and environment. Environ Sci \& Engg 6: 140-158.

11. Burghardt W, Morel JL, Zhang GL (2015) Development of soil research about urban, industrial traffic, mining and military areas (SUITMA) Soil Science and Plant Nutrition 61: 3-21.

12. Li Z, Ma Z, van der Kuijp TJ, et al. (2014) A review of soil heavy metal pollution from mines in china: Pollution and health risk assessment. Sci Total Environ 468-469: 843-853.

13. Li Q, Chen Y, Fu H, et al. (2012) Health risk of heavy metals in food crop grown on reclaimed tidal flat soil in the Pearl River Estuary, china. J Hazard Mater 227-228: 148-154.

14. Zhao H, Xia B, Fan C, et al. (2012) Human health risk from soil heavy metal contamination under different land uses near Dabaoshan Mine, Southern China. Sci Total Environ 417-418: 45-54. 
15. Naylo A, Almeida-Pereira SI, Benidire L, et al. (2019) Trace and major element contents, microbial communities, and enzymatic activities of urban soils of Marrakech city along anthropization gradient. J Soils Sediments 19: 2153-2165.

16. Aelion MC, Davisa HT, McDermott S, et al. (2009) Soil metal concentrations and toxicity: Associations with distances to industrial facilities and implications for human health. Sci Total Environ 407: 2216-2223.

17. Luo XS, Ding J, Bo X, et al. (2012) Incorporating bioaccessibility into human health risk assessments of heavy metals in urban park soils. Sci Total Environ 424: 88-96.

18. Taiwo AM, Michael JO, Gbadebo AM, et al. (2019) Pollution and health risk assessment of road dust from osogbo metropolis, osun state southwestern Nigeria. Hum Ecol Risk Assess 26: 1254-1269.

19. Van der Perk M (2006) Soil and Water Contamination. Taylor \& Francis/Balkema Group plc, London, UK, 389.

20. Lane TW, Morel FM (2009) A biological function for cadmium in marine diatoms. Proc Natl Acad Sci USA 97: 4627-4631.

21. Ukah BU, Igwe O, Ameh P (2018) The impact of industrial wastewater on the physicochemical and microbiological characteristics of groundwater in Ajao-Estate Lagos, Nigeria. Environ Monit Assess 190- 235.

22. Keller EA (2011) Environmental geology. ( $9^{\text {th }}$ edn), Pearson Eduction, New Jersy.

23. Ukah BU, Igwe O, Ubido OE (2019) Influence of Soil Particle Size Distribution on Groundwater Quality around Industrial Areas of Oshodi-Lagos Nigeria. Journal soil and water science 3: 102-111.

24. Li XY, Liu LJ, Wang YG, et al. (2013) Heavy metal contamination of urban soil in an old industrial city (Shenyang) in Northeast China. Geoderma 192: 50-58.

25. Yang D, Zhao K, Suarez F, et al. (2017) Heavy metal contamination. In: JJ Jen, J Chen, Food Safety in China: Science, Technology, Management and Regulation. (1st edn), John Wiley \& Sons Ltd, 237.

26. Jiang Y, Guo X (2019) Multivariate and geostatistical analyses of heavy metal pollution from different sources among farmlands in the Poyang Lake region, China. J Soils Sediments 19: 2472-2484.

27. Weissmannová H, Pavlovský J (2017) Indices of soil contamination by heavy metals - methodology of calculation for pollution assessment (minireview). Environ Monit Assess 189: 616.

28. Hakanson $L$ (1980) An ecological risk index for aquatic pollution control: A sedimentological approach. Water Research 14: 9751001.

29. Nriagu JO, Pacyna JM (1988) Quantitative assessment of worldwide contamination of air, water and soils by trace metals. Nature 333: 134-139.

30. Arshad MA, Martin S (2002) Identifying critical limits for soi quality indicators in agro-ecosystems. Agriculture, Ecosystems and Environment 88: 153-160.

31. Doran JW (2002) Soil health and global sustainability: Translating science into practice. Agriculture, Ecosystems and Environment. 88, 119-127.

32. Ministry of Environment (1994) Regulation of the Ministry of Environment No. 13/1994 Coll. of Czech Republic. The protection of land resources in Czech Republic. The collection of Laws of Czech Republic, 1-12.
33. Ajmone-Marsan F, Biasioli M (2010) Trace elements in soils of urban areas. Water, Air, and Soil Pollution, 213: 121-143.

34. Serbaji MM, Azri C, Medhioub K (2012) Anthropogenic contributions to heavy metal distributions in the surface and sub-surface sediments of the northern coast of Sfax, Tunisia. Int. J. Environ Res 6: 613-626.

35. Zhang G, Bai J, Xiao R, et al. (2017) Heavy metal fractions and ecological risk assessment in sediments from urban, rural and reclamation-affected rivers of the Pearl River Estuary, China. Chemosphere 184: 278-288.

36. Longe EO, Malomo S, Olorunniwo MA (1987) Hydrogeology of Lagos metropolis. Journal of African Earth Sciences 6: 163-174.

37. Chaudhury J, Mandal UK, Sharma KL, et al. (2005) Assessing Soil Quality Under Long-Term Rice- Based Cropping System. Communications in Soil Science and Plant Analysis. 36: 11411161.

38. APHA (2005) Standard methods for the examination of water and wastewater. (21 $1^{\text {st }}$ edn), American Public Health Association, Washington, DC.

39. DPR (2002) Environmental guidelines and standards for the petroleum industry in Nigeria (revised edition). Ministry of Petroleum and Natural Resources.

40. Muller G (1969) Index of geoaccumulation in sediments of the rhine river. GeoJournal 2: 108-118.

41. Martin JM, Meybeck M (1979) Elemental mass-balance of material carried by world major rivers. Mar Chem 7: 173-206.

42. Thomilson DC, DJWilson DJ, Harris CR, et al. (1980) Problems in the assessment of heavy-metal levels in estuaries and the formation of a pollution index. Mar. Res 33: 566-575.

43. Gong Q, Deng J, Xiang Y, et al. (2008) Calculating pollution indices by heavy metals in ecological geochemistry assessment and a case study in park of beijing. Journal of China University of Geosciences 19: 230-241.

44. Nemerow N (1985) Stream, lake, estuary and ocean pollution. ( $2^{\text {nd }}$ Edn), Van Nostr and Reinhold Company, New York, USA.

45. Su LY, Liu JL (2014) Multivariate analysis of heavy metal contamination in soil of Baiyangdian wetland in China. J Environ Account Manag 2: 313-323.

46. Ukah BU, Ubido OE, Igwe O (2020) Geo-statistical assessment of the soil quality and its influence on groundwater pollution in some part of Lagos State Nigeria. Modeling Earth Systems and Environment 6: 953-965.

47. Cai C, Xiong B, Zhang X, et al. (2015) Critical comparison of soil pollution indices for assessing contamination with toxic metals. Water Air Soil pollut 226: 352.

48. Li P, Qian H, Howard KWF, et al. (2015) Heavy metal contamination of yellow river alluvial sediments, northwest China. Environ Earth Sci 73: 3403-3415.

49. Nwajide CS (2013) Geology of Nigeria's sedimentary basins. CSS Bookshops Ltd, Lagos, 1-565.

50. Li P, Qian H, Howard KWF, et al. (2014) Anthropogenic pollution and variability of manganese in alluvial sediments of the Yellow River, Ningxia, northwest China. Environ Monit Assess 186: 1385-1398. 
51. Garba ST, Abubakar MA (2018) Source and distribution of the heavy metals: $\mathrm{Pb}, \mathrm{Cd}, \mathrm{Cu}, \mathrm{Zn}, \mathrm{Fe}, \mathrm{Cr}$ and $\mathrm{Mn}$ in soils of Bauchi metropolis, Nigeria. Am. J. Eng. Res 7: 13-23.
52. Barzegar R, Moghaddam AA, Soltani S, et al. (2019) Natural and anthropogenic origins of selected trace elements in the surface waters of Tabriz area, Iran. Environ Earth Sci 78: 254.

DOI: $10.36959 / 624 / 443$

Copyright: (c) 2021 Ukah BU. This is an open-access article distributed under the terms of the Creative Commons Attribution License, which permits unrestricted use, distribution, and reproduction in any medium, provided the original author and source are credited. 